\title{
KONTRIBUSI PEREMPUAN PEDAGANG SAYURAN TERHADAP PENDAPATAN KELUARGA DI PASAR BAHU MANADO
}

\author{
Yulistien Djangaopa \\ Elsje Pauline Manginsela \\ Jenny Baroleh
}

\begin{abstract}
The objectives of the research are: to find out (1) the contribution of income from trading vegetables to family income and (2) the outpouring of working hours of green vegetable traders at the Manado Bahu Market. This study used primary and secondary data. Primary data is colected through direct interviews with respondents based on the questionnaire. Secondary data were obtained from the relevant agencies, namely the Market Service Office Manado City and Sub-Office of Manado Bahu Market and literature review relating to the research topic, namely the Contribution of Women to Vegetable Traders as Family Income and the daily time spent. The sampling method used purposive sampling method which was limited to women who had ever married who sold green vegetables including kale, spinach, and gedi. The number of respondents was 15 women sellers of green vegetables. The results of the study showed that the average contribution of income per month from green vegetable traders to household income was $58.56 \%$ or Rp. 3,345,333. The average amount of time spent in a day to take care of the household is 5.33 hours per day with a percentage of $22.21 \%$, while the average time spent by women vegetable traders in Manado Bahu Market is 6.73 hours per day with a percentage of $28.04 \%$ and time for other activities, including social activities and resting, an average of 11.93 hours per day with a percentage of $49.70 \%$. *eprm*
\end{abstract}

Keywords: contribution of income, family income, green vegetable traders, Manado Bahu Market

\begin{abstract}
ABSTRAK
Tujuan penelitian yaitu: untuk mengetahui (1) kontribusi pendapatan dari berdagang sayur terhadap pendapatan keluarga dan (2) curahan waktu kerja perempuan pedagang sayuran hijau di Pasar Bahu Manado. Penelitian ini menggunakan data primer dan sekunder. Data primer dikumpulkan melalui wawancara langsung dengan responden berdasarkan daftar pertanyaan. Data sekunder diperoleh dari instansi yang terkait yaitu Kantor Dinas Pasar Kota Manado dan Sub-Dinas Pasar Bahu Manado serta telaah pustaka yang berkaitan dengan topik penelitian yaitu Kontribusi Perempuan Pedagang Sayuran terhadap Pendapatan Keluarga dan curahan waktunya. Metode pengambilan sampel dilakukan secara sengaja (purposive sampling) dengan dibatasi pada perempuan berdagang yang pernah menikah yang berjualan sayuran hijau antara lain kangkung, bayam, dan gedi. Jumlah responden sebanyak 15 perempuan penjual sayuran hijau. Hasil penelitian menunjukan kontribusi rata-rata pendapatan per bulan dari perempuan pedagang sayuran hijau terhadap pendapatan rumahtangga sebesar 58,56\% atau sebesar Rp.2.345.333. Rata-rata curahan waktu dalam satu hari untuk mengurus rumahtangga 5,33 jam per hari dengan persentase $22,21 \%$, sedangkan rata-rata waktu yang dicurahkan perempuan pedagang sayuran di Pasar Bahu Manado 6,73 jam per hari dengan persentase 28,04\%, dan waktu untuk aktifitas lain, antara lain untuk kegiatan sosial dan beristirahat, rata-rata 11,93 jam per hari dengan persentase $49,70 \%$.*eprm*.
\end{abstract}

Kata kunci: kontribusi, pendapatan keluarga, perempuan pedagang sayuran hijau, Pasar Bahu Manado 


\section{PENDAHULUAN}

\section{Latar Belakang}

Pembangunan menghasilkan perubahan struktur pekerjaan perempuan di perkotaan yang mencerminkan suatu proses pengalihan di sektor non-pertanian. Hal ini terlihat dari kosentrasi perempuan di bidang pertanian pada awal pembangunan jangka panjang tahap pertama, sedangkan pada akhir-akhir ini jumlah perempuan semakin meningkat di sektor non pertanian, seperti perdagangan, jasa, industri, dan pembantu rumah tangga di kota-kota. Namun demikian, masih ada sebagian perempuan yang hanya melakukan pekerjaan rumah tangga.

Penggunaan dan pengaturan tenaga keluarga yang tepat akan memberikan dampak yang besar terhadap pendapatan keluarga, selain itu pencurahan waktu kerja dalam suatu industri akan mempengaruhi produktif tenaga kerja (Sukardi dan Mustaniroh, 2009).

Menurut Pudjihartati (2003) dalam Kirnoprasetyo (2007), bahwa peranan ibu rumahtangga ternyata dapat mengembangkan suatu perubahan pembagian kerja dalam rumahtangga, yaitu terjadi suatu redistribusi sebagian pekerjaan rumahtangga. Handayani dan Artini (2009), menyatakan bahwa curahan tenaga kerja perempuan dapat digolongkan menjadi dua, yaitu untuk kegiatan ekonomis dan non ekonomis, lebih jau dinyatakan bahwa karena semakin banyaknya tuntutan kebutuhan hidup, maka peranan ibu rumahtangga tidak hanya berperan sebagai ibu rumahtangga saja tetapi juga berperan sebagai pencari nafka.

Hastuti (2004), menyatakan bahwa isteri seringkali mempunyai peranan sebagai tenaga kerja pada usahatani dan luar usahatani. Namun demikian tenaga kerja perempuan yang umunya bekerja di sektor pertanian memiliki kualitas pendidikan rendah, dan hanya merupakan pekerja keluarga yang umumnya tidak mendapat upah atau dinilai secara ekonomis atas jeri payanya.
Penghasilan ayah sebagai pencari nafkah utama tidak dapat mencukupi kebutuhan keluarga sehingga ibu lebih banyak melakukan pekerjaan-pekerjaan yang bersifat informal seperti berdagang, menjadi pembantu rumah tangga dan lain sebagainya. Sebagai ibu rumahtangga, biasanya perempuan yang bertanggung jawap dalam mengatur rumah tangga, baik menyangkut kesehatan gisi keluarga, pengaturan pengeluaran biaya hidup keluarga, dan biaya pendidikan anak.

Kontribusi perempuan pedagang sayuran dapat dilihat dari proporsi pendapatan pekerja wanita terhadap pendapatan keluarga. Keluarga merupakan unit terkecil dalam masyarakat yang terdiri suami, istri, dan anaknya atau ayah dan anaknya atau ibu dan anaknya (Mongid, 1995).

Dalam upaya mencari nafkah tambahan bagi keluarga. Keberhasilan suatu keluarga dalam membentuk suatu rumahtangga yang sejahtera tidak lepas dari peran seorang perempuan yang begitu besar secara khusus perempuan pedagang sayur di pasar. Baik dalam membimbing dan mendidik anak, mendampingi suami, membantu pekerjaan suami bahkan sebagai tulang punggung keluarga dalam mencari nafkah.

Dari curahan tenaga kerja ibu rumahtangga secara umum, dapat dikatakan bahwa perempuan bisa bekerja untuk mencari nafkah tambahan dalam memenuhi kebutuhan sehari-hari, curahan tenaga kerja ibu rumahtangga ini tidak hanya pada pekerjaan sebagai pedagang sayuran, disamping itu perempuan juga mengurus rumahtangga, dan aktivitas-aktivitas lainnya.

Perempuan pedagang sayuran di Pasar Bahu Manado, terutama pada ibu rumahtangga, Keadaan ini antara lain disebabkan bahwa usaha ini terdorong untuk memenuhi kebutuhan rumahtangga sehari-hari, berlangsung relatif mudah dan sederhana, tidak membutuhkan keterampilan khusus, serta modal yang digunakan relatif kecil. Oleh karena itu perempuan pedagang sayur melakukan peran sebagai pencari nafkah dan sebagai pengurus rumah tangga. Perempuan pedagang sayuran mempunyai potensi dalam peningkatan pendapatan keluarga yang nantinya akan meningkatkan kesejahteraan dalam rumahtangga. 


\section{Rumusan Masalah}

Berdasarkan latar belakang yang telah dikemukakan maka yang menjadi permasalahan dalam penelitian ini yaitu:

1. Bagaimana kontribusi pendapatan dari perempuan pedagang sayuran terhadap pendapatan rumah tangga?

2. Bagaimana curahan waktu kerja perempuan pedagang sayuran di Pasar?

\section{Tujuan Penelitian}

Penelitian ini bertujuan untuk mengetahui:

1. Kontribusi pendapatan dari perempuan pedagang sayuran.

2. Curahan waktu kerja perempuan pedagang sayuran di Pasar Bahu Manado.

\section{Manfaat Penelitian}

Penelitian ini diharapkan bermanfaat bagi peneliti untuk meningkatkan pengetahuan tentang curahan waktu kerja dan kontribusi perempuan terhadap pendapatan dalam keluarga. Menjadi bahan pertimbangan bagi pemerintah dalam menentukan kebijakan bagi rumah tangga dalam keluarga serta sebagai bahan untuk mengaplikasikan teori dan konsep yang dipelajari peneliti selama pendidikan dan bahan referensi bagi peneliti lainnya.

\section{METODE PENELITIAN}

\section{Tempat Dan Waktu Penelitian}

Penelitian ini dilaksanakan di Pasar Bahu Manado. Pemilihan lokasi penelitian berdasarkan kriteria bahwa di pasar ini banyak perempuan yang berjualan sayuran. Penelitian ini dilaksanakan mulai dari bulan Mei sampai dengan Juli 2017, sejak persiapan sampai penulisan laporan hasil penelitian.

\section{Metode Pengumpulan Data}

Penelitian ini menggunakan data primer dan data sekunder. Data primer diperoleh melalui wawancara langsung dengan responden berdasarkan daftar pertanyaan yang telah disiapkan sebelumnya. Data sekunder diperoleh dari instansi yang terkait langsung dengan penelitian dalam hal ini Kantor Dinas Pasar Kota Manado Sub-Dinas Pasar Bahu Manado serta telaah pustaka yang berkaitan dengan penelitian ini.

\section{Metode Pengambilan Sampel}

Pengambilan sampel dilakukan secara sengaja (Purposive Sampling) dengan dibatasi pada perempuan berdagang yang berjualan sayuran hijau yang pernah menikah. Jumlah sampel sebagai responden yaitu sebanyak 15 perempuan penjual sayuran hijau.

\section{Konsep Pengukuran Variabel}

Pengukuran variabel dalam penelitian ini yaitu:

1. Karakteristik responden dalam hal ini perempuan pedagang sayuran yang hanya pada ibu ruma tangga, berupa umur, tingkat pendidikan, jumlah tanggungan keluarga, lamanya berjualan sayuran, dan pekerjaan suami.

2. Curahan waktu oleh perempuan yang beraktifitas sebagai penjual sayuran dan pada aktifitas rumah tangga. (waktu yang di perlukan dalam aktifitas berjualan dan melakukan aktifitas rumah tangga dalam keluarga dihitung dalam jumlah jam/hari) (1 x 24 jam)

3. Pendapatan ibu rumah tangga yang beraktivitas dibidang penjualan sayuran $\mathrm{Rp} / \mathrm{bulan}$.

4. Perempuan pedagang sayuran yang ber usaha sebagai berdagang : ibu ruma tangga, suami dan anak (perempuan dan laki-laki)

5. Pendapatan dalam keluarga di hitung berdasarkan:

a. Pendapatan istri yaitu: pendapatan ibu rumah tangga yang didapat dari hasil penjualan sayuran dikurangi biaya pengeluaran dalam berjualan (retribusi, kebersihan, angkutan dan tenaga kerja) (Rp/bulan)

b. Pendapatan suami yaitu pendapatan yang diperoleh dari berbagai pekerjaan yang di jalankan, yang dihitung berdasarkan (Rp/bulan).

c. Pendapatan keluarga yaitu dari anak lakilaki dan perempuan yang belum menikah tapi sudah bekerja yang tinggal serumah dan makan satu dapur (Rp/bulan). 


\section{Metode Analisis Data}

Penelitian dianalisis secara deskriptif (descriptive analysis) (Sugiyono, 2003) dimana penelitian dilakukan untuk mengkaji karakteristik perempuan pedagang sayuran, curahan waktu, usaha serta kontribusi terhadap pendapatan rumah tangga.

Kemudian dibuat kesimpulan untuk menjawap permasalahan penelitian dengan langkah-langkah sebagai berikut: a). Mereduksi data, kalau banyak disederhanakan dan disesuaikan. b). Display data, mengklasifikasikan masing-masing data supaya lebih jelas dan c). Pengambilan kesimpulan.

Semua data yang dianalisis disajikan dalam bentuk tabel, agar dapat dilihat besarnya kontribusi perempuan sebagai ibu rumah tangga terhadap pendapatan keluarga di Pasar Bahu Manado.

Formula rumus yang digunakan adalah:

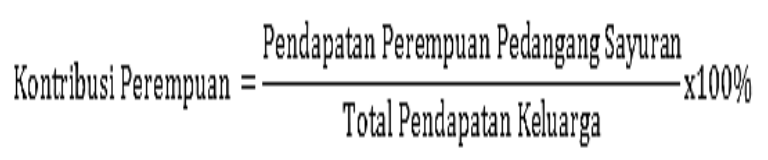

\section{HASIL DAN PEMBAHASAN}

\section{Gambaran Umum Pasar Bahu Manado}

Pasar Bahu merupakan salah satu pasar tradisional kelima terbesar setelah pasar Tuminting yang ada di kota Manado. Wilayah Studi adalah Kawasan Pasar Tradisional Bahu, dimana menurut sejarah pasar tradisional ini, ada pada tahun 1966 dan disebut sebagai Pasar 66. Kegiatan Pasar 66 yang dulunya hanya ada di sore hari, kemudian pasar ini berubah nama sebagai Pasar Kilat. Pasar kilat yang sekarang di sebut sebagai Pasar Bahu, karena keberadaan pasar yang berada di Kelurahan Bahu di Kecamatan Malalayang hingga sekarang.

Luas pasar Bahu menurut data Dinas Pasar Kota Manado yaitu $1.600 \mathrm{~m}$ persegi dengan jumlah pedagang yang berjualan sebanyak 132 pedagang, termasuk didalamnya perempuan pedagang sayuran. Aktivitas pasar ini berlangsung setiap hari dimulai dari jam 04.00 subuh sampai jam 21.00 (jam 9 malam). Aktivitas paling ramai berlangsung dari jam 07.00 sampai jam 10.00 dimana pada jam-jam tersebut sangat ramai dengan orang yang berbelanja. Pada jam 12.00 sampai jam 15.00 agak sepi dan nanti sekitar jam 16.00 mulai ramai lagi dan berhenti pada jam 21.00.

Adapun jenis sayuran yang diperdagangkan oleh wanita di pasar ini yaitu: caisin, kangkung, bayam, gedi, daun ubi, daung bawang, rempah-rempah campur (baramakusu, daun lemon, balakama). Petsai, pok coy, seldrei, daun lailem, daun papaya, daun ganemo (sayuran berwarna hijau), patura kol, bunga kol, labu, (sambiki), kentang, wortel, rebung, kacang panjang, buncis, paria, terong, bunga papaya, ketimun dan ketimun jepang.

\section{Deskripsi Responden}

Responden yang menjadi sampel dalam penelitian ini ialah para perempuan pedagang sayuran yang perna menikah dan berjualan di pasar tidak tinggal di lapak dan pulang ke rumah setiap hari untuk mengurus rumahtangga.

Berikut ini dijelaskan karakteristik responden menurut umur, lama berdagang sayuran, tingkat pendidikan, dan jumlah anggota dalam tanggungan keluarga, serta penghasilan, pekerjaan anggota keluarga lainnya, serta alasan perempuan berdagang sayuran.

\section{Umur Responden}

Total keseluruhan jumlah penduduk yang ada di Kelurahan Buha sebanyak 9.368 jiwa, yang terdiri dari 2.565 Kepala Keluarga.

Umur responden akan mempengaruhi kemampuan fisik bekerja dan cara berpikir reponden. Kemampuan kerja responden akan terus bertambah pada satu tingkat umur tertentu, Umur juga mempunyai hubungan dengan lamanya berdagang sayuran, pengalamannya menjalani kehidupan sebagai individu dalam interaksinya dengan individu lain dalam lingkungan sosial, bahkan lingkungan fisik alamiah.

Seiring dengan hal di atas, demikian juga yang terjadi di Pasar Bahu Manado. Berdasarkan dari hasil pengamatan,walaupun kebanyakan didapat bahwa ibu rumah tangga yang masi aktif bekerja rata-rata berumur antara 50-59 tahun, tetapi kisaran umur ini 
masih merupakan umur produktif untuk bekerja, dan di Pasar Bahu Manado kisaran umur mendominasi jumlah angkatan kerja responden yaitu sebesar $60,00 \%$, kemudian secara berturut-turut diikuti oleh responden yang berumur 41-50 tahun sebesar 26,67\% dan terakhir umur kurang dari 51 tahun sebesar $13,33 \%$. Hal ini dapat dilihat pada Tabel 1.

Tabel 1. Distribusi Responden Menurut Kelompok Umur

\begin{tabular}{lcr}
\hline Kelompok Umur (Tahun) & Jumlah (Responden) & Persentase (\%) \\
\hline$<40$ & 2 & 13,33 \\
$41-50$ & 4 & 26,67 \\
$>51$ & 9 & 60,00 \\
\hline Jumlah & 15 & 100 \\
\hline
\end{tabular}

Tabel 1 menunjukkan bahwa, responden yang berumur lebih dari 40 tahun dan kurang dari 51 tahun yang bekerja sebagai pedagang sayuran menduduki jumlah yang paling kecil yaitu 2 orang. Penyebab dari hal ini adalah karena persepsi pemikiran bahwa bekerja sebagai pedagang sayuran sangat mudah di kerjakan. Sedangkan pedagang sayuran yang berumur kurang dari 51 tahun, dimana karena mereka sudah berusia lanjut, mereka lebih memilih bekerja sebagai pedagang sayuran, karena kemampuan atau keadaan fisik yang suda semakin menurun dan yang dirasa masih mampu untuk mereka lakukan.

Berbeda dengan responden yang berumur di kisaran 41-50 walaupun kemampuan fisik mereka yang masih baik tetapi karena keterampilan yang mereka miliki yang tidak mendukung untuk bekerja di sektor lain, maka mereka hanya bekerja sebagai pedagang sayuran serta pendapatan yang dirasa suda bisa membantu ekonomi keluarga, maka responden yang melakoni pekerjaan sebagai pedagang sayuran di samping sebagai ibu rumah tangga yang mengurus rumah tangga.

\section{Pengalaman Berdagang Sayuran}

Pengalaman berdagang sayuran mempengaruhi keputusan-keputusan yang diambil dan ketahanan dalam menghadapi berbagai permasalahan yang muncul dalam proses berdagang. Sebab perempuan pedagang sayuran yang lebih berpengalaman akan lebih mengenal kelebihan dan kelemahan usahanya yang dilakukan sehingga lebih siap menghadapi permasalahan yang mungkin timbul.
Dilihat dari pengalaman usaha pedagang sayuran, maka hampir semua pedagang responden mempunyai pengalaman lebih dari sepuluh tahun. Pengetahuan tentang pedagang sayuran didapat baik turun-temurun dari orang tua mereka maupun dari teman sesama mereka.

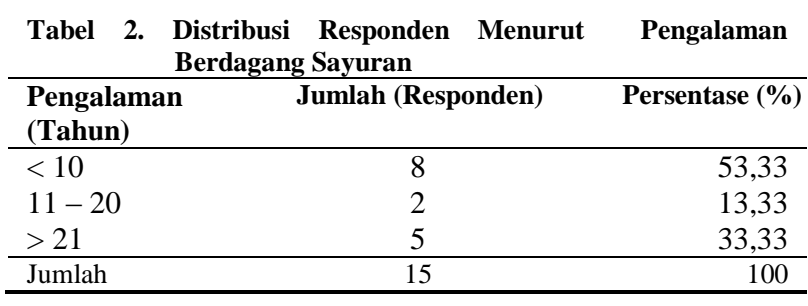

Tabel 2 menunjukkan bahwa, responden yang berpengalaman bekerja sebagai pedagang sayuran yang berjumlah paling sedikit yaitu 2 orang. Pengalaman sebagai pedagang sayuran dapat berlangsung lamah jika respondennya tidak berpindah-pindah pekerjaan sebagai pedagang sayuran.

\section{Tingkat Pendidikan}

Tingkat pendidikan perempuan pedagang sayuran dapat mempengaruhi produktifitasnya di dalam mengelolah sayuran di Pasar Bahu.

Tabel 3 menunjukkan variasi tingkat pendidikan ibu rumah tangga yang menjadi responden, menempuh pendidikan hanya sampai jenjang Sekolah Dasar (SD) yaitu sebesar 26,67\%, kemudian diikuti oleh responden dengan jenjang pendidikan Sekolah Menengah Atas (SMA) sebesar 33,33\%, dan jenjang pendidikan Sekolah Menengah Pertama (SMP) sebesar 40,00\%.

Tabel 3. Distribusi Responden Menurut Tingkat Pendidikan

\begin{tabular}{lcr}
\hline $\begin{array}{l}\text { Tingkat } \\
\text { Pendidikan }\end{array}$ & $\begin{array}{c}\text { Jumlah } \\
\text { (Responden) }\end{array}$ & Persentase (\%) \\
\hline SD & 4 & 26,67 \\
SLTP & 6 & 40,00 \\
SLTA & 5 & 33,33 \\
\hline Jumlah & 15 & 100 \\
\hline
\end{tabular}

Besarnya persentase responden yang pendidikannya hanya sampai pada tingkat pendidikan Sekolah Menengah Pertama (SMP), yang bekerja sebagai pedagang sayuran, setelah diteliti, ada juga yang ingin sekolah lebih tinggi tetapi mereka tidak mempunyai biaya untuk menempuh ke jenjang yang lebih tinggi. 
Berbeda dengan responden yang dulunya pernah menempuh pendidikan sampai pada tingkat Sekolah Menengah Atas (SMA), tetapi ada sebagian yang akhirnya harus juga bekerja sebagai pedagang sayuran karena selain tidak ada biaya untuk ke jenjang yang lebih tinggi, yang hanya bekerja untuk mengurus rumah tangga, dan pada akhirnya mereka bekerja untuk membantu suami dengan bekerja sebagai pedagang sayuran.

Dari pemikiran di atas, ada juga sebagian responden yang berpendapat bahwa bekerja di sektor lain memerlukan keterampilan khusus (non petani), mereka tidak memiliki keterampilan khusus tersebut, yang akhirnya juga mereka hanya bekerja pedagang sayuran, para ibu rumah tangga yang menjadi responden merasa bahwa bekerja sebagai pedagang sayuran, mereka merasa hal ini cukup membantu suami dalam membiayai kebutuhan hidup sehari-hari.

\section{Jumlah Anggota dalam Keluarga}

Jumlah atau banyaknya anggota keluarga mempunyai hubungan erat dengan umur responden sebagai pedagang sayuran di pasar. Jumlah anggota dalam keluarga mempengaruhi pendapatan per kapita. Makin banyak jumlah dalam suatu keluarga makin besar biaya yang harus dikeluarkan, makin sedikit jumlah anggota keluarga makin sedikit juga biaya yang dikeluarkan. Jumlah anggota keluarga merupakan salah satu alasan utama bagi para ibu rumah tangga turut serta dalam membantu suami untuk bekerja agar dapat memperoleh penghasilan.

Jumlah anggota keluarga merupakan banyaknya orang yang dibiayai dalam suatu rumah tangga.

Tabel 4. Distribusi Responden Menurut Anggota Keluarga

\begin{tabular}{lcr}
\hline $\begin{array}{l}\text { Jumlah Anggota } \\
\text { Keluarga }\end{array}$ & $\begin{array}{c}\text { Jumlah } \\
\text { (Responden) }\end{array}$ & Persentase (\%) \\
\hline 2 & 6 & 40,00 \\
3 & 5 & 33,33 \\
4 & 4 & 26,67 \\
\hline Jumlah & 15 & 100 \\
\hline
\end{tabular}

Tabel 4 menunjukkan bahwa responden yang bekerja sebagai pedagang sayuran untuk membiayai keluarga dengan jumlah yang paling banyak yaitu 4 anggota keluarga, sehingga biaya yang di keluarkan menjadi besar, hal ini juga sebagian responden anggota keluarga yang lain telah mati, dan telah menikah atau pisah rumah sehingga jumlah biaya yang di keluarkan nya juga menjadi kecil.

\section{Pendapatan Perempuan Pedagang Sayuran}

Tabel 5 memberikan gambaran mengenai pendapatan bersih perempuan pedagang sayuran. Pendapatan responden dimaksud ialah dari hasil pendapatan bersih per hari yang di terima dalam bentuk penjualan sayuran. Penghasilan ini ada responden yang mendapatkan Rp.60.000 - Rp.75.000/ hari, Rp.100.000 - Rp.200.000 per hari dan ada yang Rp.300.000/hari.

Tabel 5. Pendapatan Bersih Perempuan Pedagang Sayuran di Pasar Bahu Manado (Rp/Bulan)

\begin{tabular}{lcr}
\hline $\begin{array}{l}\text { Penghasilan } \\
\text { (Rp/Bulan) }\end{array}$ & Jumlah (Responden) & Persentase (\%) \\
\hline$\leq 2.450 .000$ & & 86,66 \\
$>2.450 .000$ & 13 & 13,33 \\
\hline Jumlah & 2 & 100 \\
\hline
\end{tabular}

Tabel 5 menunjukkan bahwa pendapatan 15 responden perempuan pedagang sayuran diatas dapat dilihat bahwa di dalam $\mathrm{Rp} /$ bulan terdapat variasi dari segi jumlah pendapatan. Responden yang bekerja sebagai pedagang sayuran masingmasing memiliki pendapatan yang rendah berjumlah $86,66 \%$ ada 13 orang dan pendapatan tinggi masing-masing berjumlah $13,33 \%$ ada 2 orang, sebagian responden yang mengambil bahan sayurannya dari kebun mereka sendiri dan sebagian juga dari pemasok sayuran ini.

\section{Alasan Bekerja Sebagai Pedagang Sayuran}

Tabel 6 menunjukkan jawaban 15 orang responden mengenai alasan bekerja sebagai pedagang sayuran, terlihat bahwa responden yang memilih pekerjaan ini menduduki jumlah yang paling kecil, yaitu masing-masing 8 dan 3 orang. Penyebab dari hal ini adalah karena mereka menganggap bahwa lebih cepat mendapatkan uang dan bisa mencukupi kebutuhan keluarga. 
Tabel 6. Alasan Memilih Pekerjaan Berjualan Sayuran di Pasar

\begin{tabular}{|c|c|c|c|}
\hline No & Alasan & Jumlah & Persentase (\%) \\
\hline 1 & Mudah dikerjakan & 15 & 100,00 \\
\hline 2 & $\begin{array}{l}\text { Tidak punya } \\
\text { keterampilan lain }\end{array}$ & 10 & 66,7 \\
\hline 3 & $\begin{array}{l}\text { Tidak ada pekerjaan } \\
\text { lain }\end{array}$ & 15 & 100,00 \\
\hline 4 & $\begin{array}{l}\text { Langsung menerima } \\
\text { uang }\end{array}$ & 14 & 93,3 \\
\hline 5 & $\begin{array}{l}\text { Menambah } \\
\text { penghasilan keluarga }\end{array}$ & 15 & 100,00 \\
\hline 6 & $\begin{array}{l}\text { Tidak perlu modal } \\
\text { yang besar }\end{array}$ & 12 & 80,0 \\
\hline 7 & Biaya sekolah anak & 8 & 53,3 \\
\hline 8 & $\begin{array}{l}\text { Meneruskan usaha } \\
\text { dari orang tua }\end{array}$ & 3 & 20,0 \\
\hline
\end{tabular}

Para responden mempunyai alasan yang berbeda-beda dan mereka menganggap aktivitas ini sangat mudah dijalankan. Di samping itu, keterampilan dan kebiasaan sangat menentukan pula. Mereka memperoleh pengalaman dari orang tua, yang pada umumnya telah lebih dahulu berdagang sayuran di pasar. Usaha ini tetap mereka pertahankan maupun dilanjutkan dan usaha ini merupakan pilihan utama dalam mencukupi kebutuhan keluarga.

Adanya tuntutan tanggung jawab ekonomi terhadap kelangsungan ekonomi rumah tangga responden, menyebabkan mereka harus bekerja untuk mendapatkan penghasilan tambahan sebagai penyokong ekonomi rumah tangga. Sehingga bekerja adalah merupakan keharusan, dijawab oleh sebagian besar responden penelitian. Pendapatan rumah tangga responden diprioritaskan alokasinya untuk pemenuhan kebutuhan makanan, pendidikan, dan kebutuhan lain (listrik, air, iuran desa). Pemenuhan kebutuhan pakaian tidak menjadi prioritas bagi mereka.

Hal ini didukung pula oleh penelitian (Abdullah, 2001), mengungkapkan bagaimana perempuan bakul memiliki kebanggaan dan kepercayaan diri yang tinggi. Berdagang ternyata dapat meningkatkan status perempuan, sebab dengan begitu mereka memiliki kemampuan secara ekonomi, memiliki kepercayaan diri karena meningkatnya andil mereka dalam ekonomi rumah tangga, dan memiliki kepuasan pribadi dengan menjalin relasi sosial dengan teman-teman sesama bakul.
Imbalan ekonomi dari kegiatan berdagang kecil-kecilan itu memang tidak memberikan penghasilan yang besar. Namun, berada di luar rumah dan di luar pertanian dalam beberapa jam sehari telah memberikan kepuasan lain bagi perempuan. Dengan berdagang perempuan menemukan jaringan dan kelompok yang memberikan ruang ekspresi.

\section{Hasil Penelitian}

\section{Rata-rata Pendapatan Anggota Rumah Tangga Responden}

Kontribusi rata-rata pendapatan dari masing-masing anggota rumah tangga dari perempuan pedagang sayuran ditunjukkan pada Tabel 7.

Pendapatan keluarga pada Tabel 7 terdiri dari pendapatan rata-rata istri yang berjualan sayuran, rata-rata pendapatan suami dan ratarata pendapatan anak yang masih tinggal serumah belum berkeluarga namun sudah bekerja dan memperoleh penghasilan. Pendapatan istri sebagai pedagang sayuran merupakan penerimaan bersih setiap hari setelah dikurangi dengan membayar retribusi, biaya tenaga kerja, biaya kebersihan dan biaya transportasi.

Tabel 7. Rata-rata Kontribusi Terhadap Pendapatan

\begin{tabular}{lccr}
\multicolumn{4}{c}{ Keluarga dalam Rp/Bulan } \\
\hline $\begin{array}{c}\text { Anggota } \\
\text { Rumah } \\
\text { Tangga }\end{array}$ & $\begin{array}{c}\text { Total } \\
\text { Pendapatan } \\
(\text { Rp/Bulan) }\end{array}$ & $\begin{array}{c}\text { Rata-rata } \\
\text { Pendapatan } \\
(\text { Rp/Bulan) }\end{array}$ & $\begin{array}{r}\text { Kontribusi } \\
(\%)\end{array}$ \\
\hline Istri & 35.180 .000 & 2.345 .333 & 58,56 \\
Suami & 13.500 .000 & 900.000 & 22,47 \\
Anak yang & 11.400 .000 & 760.000 & 18,97 \\
bekerja \\
$\begin{array}{l}\text { Total rata-rata pendapatan } \\
\text { keluarga pedagang sayuran } \\
\text { hijau }\end{array}$ & $4,005,333$ & 100,00 \\
\end{tabular}

\section{Curahan Waktu Responden Dalam Rumah Tangga}

Pemanfaatan waktu untuk kerja bagi seseorang, merupakan salah satu faktor yang sangat berpengaru pada tinggi rendanya tingkat pendapatan. Faktor ini juga yang turut mempengaruhi ibu rumah tangga yang menjadi responden, ataupun yang mengurus rumah tangga. Berikut ini Pembagian kerja dan curahan waktu di antara perempuan pedagang sayuran, disajikan pada Tabel 8. 
Tabel 8. Rata-rata Curahan Waktu Kerja Responden Dalam Rumah

\begin{tabular}{|c|c|c|c|c|}
\hline \multirow[t]{2}{*}{ No. Resp } & \multicolumn{3}{|c|}{ Curahan Waktu Responden (jam/\%) } & \multirow{2}{*}{$\begin{array}{r}\text { Persentase } \\
(\text { jam/\%) } \\
\end{array}$} \\
\hline & $\begin{array}{c}\text { Mengurus } \\
\text { Rumah } \\
\text { Tangga } \\
\text { Jam (\%) }\end{array}$ & $\begin{array}{c}\text { Berjualan } \\
\text { Sayur Jam }(\%)\end{array}$ & $\begin{array}{c}\text { Aktivitas Lain } \\
\text { Jam (\%) }\end{array}$ & \\
\hline 1 & $6(25,00)$ & $6(25,00)$ & $12(50,00)$ & $24(100)$ \\
\hline 2 & $5(20,83)$ & $7(29,17)$ & $12(50,00)$ & $24(100)$ \\
\hline 3 & $4(16,67)$ & $8(33,33)$ & $12(50,00)$ & $24(100)$ \\
\hline 4 & $6(25,00)$ & $8(33,33)$ & $10(41,67)$ & $24(100)$ \\
\hline 5 & $5(20,83)$ & $7(29,17)$ & $12(50,00)$ & $24(100)$ \\
\hline 6 & $4(16,67)$ & $6(25,00)$ & $14(58,33)$ & $24(100)$ \\
\hline 7 & $7(29,17)$ & $8(33,33)$ & $9(37,50)$ & $24(100)$ \\
\hline 8 & $4(16,67)$ & $5(20,83)$ & $15(62,50)$ & $24(100)$ \\
\hline 9 & $5(20,83)$ & $7(29,17)$ & $12(50,00)$ & $24(100)$ \\
\hline 10 & $6(25,00)$ & $6(25,00)$ & $12(50,00)$ & $24(100)$ \\
\hline 11 & $7(29,17)$ & $6(25,00)$ & $11(45,83)$ & $24(100)$ \\
\hline 12 & $5(20,83)$ & $7(29,17)$ & $12(50,00)$ & $24(100)$ \\
\hline 13 & $6(25,00)$ & $7(29,17)$ & $11(45,83)$ & $24(100)$ \\
\hline 14 & $4(16,67)$ & $6(25,00)$ & $14(58,33)$ & $24(100)$ \\
\hline 15 & $6(25,00)$ & $7(29,17)$ & $11(45,83)$ & $24(100)$ \\
\hline Total & $80(333,34)$ & $101(420,84)$ & $179(745,82)$ & $24(100)$ \\
\hline Rata-rata & $5,33(22,21)$ & $6,73(28,04)$ & $11,93(49,70)$ & \\
\hline
\end{tabular}

Tabel 8 menunjukkan bahwa, dari setiap jenis kegiatan ibu rumah tangga dalam usaha berdagang terdapat variasi dari segi curahan waktu. Kegiatan rumah tangga dapat diklasifikasikan menjadi;

1. Kegiatan yang berkaitan dengan rumah tangga (home production) yang mencakup memasak, mencuci, membersikan rumah serta merawat suami dan anak. Rata-rata curahan waktu tenaga kerja yang di curahkan responden dalam megurus rumah tangga adalah 5,33 dalam satu hari dengan persentase $22,21 \%$.

2. Kegiatan mencari nafkah, dalam hal ini berjualan sayuran di pasar. Rata-rata curahan waktu untuk berjualan sayuran adalah 6,73 dengan persentase 28,04\% dalam satu hari.

3. Aktivitas lain, kegiatan yang dilakukan diluar mengurus rumah tangga dan berjualan sayuran adalah Ibadah kolom, Pembinaan Kesejahteraan Keluarga (PKK), Arisan, Pergi ke Kebun, dan Nonton TV. Rata-rata curahan waktu responden untuk aktivitas lainnya adalah 11,93 dengan persentase $49,70 \%$.

\section{Pembahasan}

Perempuan pedagang sayuran di pasar Bahu umumnya berstatus ibu rumah tangga yang pernah menikah, ada pula anak yang belum menikah yang menjadi tanggungan karena tinggal serumah. Pada umumnya usaha berjualan sayuran ini dimulai setelah perempuan kawin. Perempuan merasa perlu membantu suami mencari nafkah karena penghasilan dari suami tidak mencukupi. Sebaliknya, suami memberi dukungan karena mereka merasakan tekanan ekonomi lebih besar bila hanya mengandalkan penghasilan rumah tangga dari suami sendiri.

\section{Curahan Waktu Mengurus Rumah Tangga}

Curahan waktu dari masing-masing perempuan pedagang sayuran pada waktu pagi hari berbeda-beda, waktu bangun pagi berkisar antara jam 3 sampai jam 5 pagi. Kegiatan yang dilakukan antara lain; beresberes rumah, menyiapkan makanan untuk suami dan anak.

Perempuan pedagang sayuran ini mempunyai waktu untuk pulang ke rumah berbeda-beda, ada yang pulang ke ruma jam 10 pagi dan ada pula yang pulang ke rumah jam 12 siang, penyebabnya adalah jika bahan sayuran yang dijual tidak cepat habis terjual atau tidak laku, maka mereka pulang ke rumah dengan waktu yang lama, begitu juga sebaliknya jika bahan sayuran yang dijual cepat habis terjual atau laku, maka mereka pulang ke rumah juga dengan waktu yang cepat. Perempuan pedagang sayuran bisa membagi waktu untuk berjualan sayuran, mengurus rumahtangga, dan aktifitas lain.

\section{Curahan Waktu Perempuan Pedagang Sayuran di Pasar}

Curahan waktu dari masing-masing perempuan pedagang sayuran pada waktu pagi hari berbeda-beda, waktu bangun pagi berkisarklmk;jkl

Perempuan dengan statusnya sebagai istri mempunyai peran yang berhubungan dengan kedudukannya sebagai ibu rumah tangga. Aktivitas-aktivitas dalam rumah tangga merupakan realisasi peran domestik yang dikenal pula sebagai produksi domestik. Perempuan berangsur-angsur tidak lagi terbelenggu dalam peran domestik saja. Hal ini disebabkan semakin beratnya tuntutan untuk memenuhi kebutuhan hidup rumah tangga dan semakin luas hubungan sosial perempuan di dalam masyarakat. 
Curahan waktu tenaga kerja perempuan pedagang sayuran yang menjadi responden berbeda-beda. Waktu, persiapan dan penjualan sayuran yang dilakukan oleh perempuan pedagang sayuran antara lain ;

1. Bangun Pagi dan Persiapan ke Pasar

Waktu bagun pagi dari responden perempuan pedagang sayuran bervariasi, yaitu berkisar antara jam 3 sampai jam 5 pagi. Persiapan yang dilakukan oleh perempuan pedagang sayuran sebelum ke pasar adalah menyiapkan bahan-bahan sayuran, bahan sayuran dari perempuan pedagang sayuran berbeda-beda. Ada yang memiliki jualan sayuran hasil dari kebun milik sendiri dan ada juga yang membeli langsung dari supplier atau pedagang pengumpul yang ada di pasar karombasan dan dijual kembali di pasar bahu.

2. Waktu Berjualan di Pasar

Waktu berjualan sayuran dari perempuan pedagang sayuran rata-rata sama yaitu mulai dari jam 5 pagi sampai jam 12 siang. Waktu habis terjualnya bahan jualan sayuran dari 15 responden perempuan pedagang sayuran berbeda-beda. Ada yang jualanya habis terjual jam 10, ada juga yang habis jam 11, dan ada juga yang habis terjual jam 12 siang.

\section{Curahan Waktu Melakukan Aktifitas Lain}

Curahan waktu yang dilakukan perempuan pedagang sayuran ini juga berbeda-beda. Kegiatan-kegiatan yang dilakukan yaitu arisan (sebulan sekali, seminggu sekali, dan setiap hari), dan ada sebagian yang tidak mengikuti arisan. Ada juga yang mengikuti ibada rukun, ibada kaum ibu, pembinaan kesejateraan keluarga (pkk), ibada kolom dan ada juga yang tidak mengikutinya di karenakan ada hambatan atau lain-lain.

Di hari-hari tertentu membereskan rumah, memasak, makan bersama suami dan istri, menyuci pakaian, istrahat tidur siang atau menonton TV, pergi ke kebun, kunjungi ke rumah teman, nongkrong dengan teman-teman, dan pergi ke moll.

\section{Kontribusi Perempuan Pedagang Sayuran Terhadap Pendapatan Rumah Tangga}

Kontribusi pendapatan setiap anggota rumahtangga pada setiap aktivitas kerjanya yang lebih besar merupakan konsekuensi dari proporsi curahan kerja setiap anggota keluarga yang besar pada aktivitas tersebut. Dari total pendapatan rumahtangga dapat diungkapkan bahwa kontribusi istri sebagai ibu rumahtangga yang berdagang sayuran di pasar, lebih besar dari kontribusi suami dan anggota keluarga lainnya. Hal ini menunjukkan bahwa setiap anggota keluarga bersama-sama mencari nafkah untuk memenuhi kebutuhan hidup rumahtangganya.

\section{KESIMPULAN DAN SARAN}

\section{Kesimpulan}

Kontribusi rata-rata pendapatan per bulan dari perempuan pedagang sayuran hijau relatif besar di bandingkan dengan anggota keluarga lainnya, rata-rata curahan waktu dalam satu hari dalam rumahtangga kerja yang lebih besar merupakan konsekuensi dari proporsi curahan kerja setiap anggota keluarga yang besar pada aktifitas tersebut. Oleh karena itu Perempuan pedagang sayuran memiliki peranan penting dalam kebutuhan sehari-hari.

\section{Saran}

Usaha di sektor informal ini memiliki pendapatan yang cukup memuaskan bagi perempuan pedagang sayuran sehingga pendapatan yang diperoleh dapat tercapai dalam keperluan lainnya sebaiknya bisa disisihkan juga untuk tabungan dan modal usaha, sehingga usahanya dapat berkembang.

\section{DAFTAR PUSTAKA}

Abdullah, Irwan. 2001. Seks, Gender \& Reproduksi Kekuasaan, Yogyakarta: Tarawang Press. 
Th dan Ni Wayan Putu Artini. 2009. Kontribusi Pendapatan Ibuh Rumah Tangga Pembuat Makanan Olahan Terhadap Pendapatan Keluarga. Jurnal Volume V No. 1 Juli 2009. Jurusan Sosial Ekonomi Fakultas Pertanian Universitas Udayana. Scholar Google. co.id. Diakses tanggal 1/6/2017.

Handayani dan Artini, 2009. Kontribusi Pendapatan Ibu Rumahtangga Pembuat Makanan Olahan Terhadap Pendapatan Keluarga. $\quad$ http://www.pdfio./k314625.html.

Hastuti E. L. 2004. Hambatan Sosial Budaya Dalam Pengarusutamaan Gender Di Indonesia (Socio-Cultural Constraints on Gender Mainstreaming in Indonesia). Pusat Penelitian dan Pengembagan Sosial Ekonomi Pertanian, Bogor.
Mongid, A. 1995. Gerakan Pembangunan Keluarga Sejahtera. Jakarta: BKKBN.

Pudjihartati. 2003. dalam Kirnoprasetyo I. 2007. Peranan Wanita Tani Dalam Perekonomian Keluarga Petani Di Pedesaan (Utopia, Konseptual dan Realita). Fakultas Pertanian Universitas Wisnuwardhana, Malang.

Kirnoprasetyo, I. 2007. Peranan Wanita Tani Dalam Perekonomian Keluarga Petani Di Pedesaan (Utopia, Konseptual dan Realita). Fakultas Pertanian Universitas Wisnuwardhana, Malang.

Sugiyono. 2003. Metode Penelitian Administrasi. Alfabeta. Bandung.

Sukardi dan Mustarino, S.A. 2009. Analisis Alokasi Curahan Waktu Kerja Tenaga Kerja Keluarga Pada Industri Tempe Di Sanan Kota Malang. Jurusan Teknologi Industri Pertanian, Fakultasi Teknologi Pertanian.Universitas Brawijaya. 